\title{
Sedimentation Modeling For Development of Kenjeran - Surabaya
}

\author{
Winda Amalia Herdianti $^{1, *}$, Suntoyo ${ }^{2}$, and Wahyudi ${ }^{3}$ \\ ${ }^{1}$ Master Student, Department of Ocean Engineering, Faculty of Marine Technology, Institut \\ Teknologi Sepuluh Nopember, Surabaya, Indonesia (60111) \\ ${ }^{2}$ Associate Professor, Ocean Engineering Department, Faculty of Marine Technology, Institut \\ Teknologi Sepuluh Nopember (ITS), Surabaya, Indonesia (60111). \\ ${ }^{3}$ Assistant Professor, Ocean Engineering Department, Faculty of Marine Technology, Institut \\ Teknologi Sepuluh Nopember (ITS), Surabaya, Indonesia (60111).
}

\begin{abstract}
Surabaya City administratively has a maritime boundary consisting of 11 districts known as Pantai Timur Surabaya (Pamurbaya). One of them is Kenjeran area. The area located in the Development Unit 3 in the Urban Spatial Plan (RTRW) used as a Service and Trade Area and also used as a Tourism Area. Therefore, this study is important to know the shoreline changes and made recommendations in zone management development. Results of this study found that the area of Kenjeran dominated by sedimentation with sedimentation range $0.002-0.015$ meters. The largest sedimentation is $2.36 \times 10^{6} \mathrm{~m}^{2}$ with sedimentation of 0.02 meters. Development of the area in Kenjeran is suitable with the RTRW Surabaya, but due to the large sedimentation, there are some things that must be considered such as the uncertainty of land ownership arise in Kenjeran and ecosystem damage. The solution offered is that the government should restrict the use of arising land and there should be clarification of rules from the government on arising land.
\end{abstract}

Keyword: Sedimentation, Morphological Changes, Kenjeran-Surabaya

\section{Introduction}

Coastal area is an area between land and sea, landward covering the land part, either dry or submerged, which is still affected by the nature of the sea such as tides, and sea breeze. Meanwhile towards the sea compromise of the sea that is still influenced by natural processes that occur on land such as sedimentation and fresh water current, or caused by human activities on land such as deforestation and pollution.

The sediment transport process is one of the main proccess in coastal areas. Sediment transport is a displacement of sediment material from a certain place to another. This move is in the form of inflow or outflow. If the outflow is more than the inflow then there will be erosion and vice versa if the outflow is less than the inflow then the accretion process occurs [1, 2, 3]. Generally sediment transport movement is divided into three which is bed load, wash load and suspended load. Wash Load is very fine particles which are transported by the water, but those particles do not exist on the bed. Hence, wash load will not be considered. Suspended load is defined as part of the total transport load which is moving without continous contact with the bed as the result of the agitation of the fluid turbulence. The appearance of ripples will increase

\footnotetext{
*Corresponding author: windaherdianti@gmail.com
} 
the bed shear stress (flow resistance) [2, 3]. On the other hand, more grains will be suspended due to the flow separation on the lee side of the ripples. Thus the suspended load is related to the total bed shear stress [3]. Bed load is defined which has more or less continuous contact with the bed, the particles are simply rolling, trundle or small jumping at the bottom because of the relatively slow flow rate. Bed load sediment transport modelling under non-linier and irregular waves motion based on bottom shear stress model has been done by $[4,5,6,7]$. One of the formulas used to calculate the bed load transport by using the DELFT 3D software in the present study is the Engelund Hansen formula [3], as follows

$$
S=S b+S s, e q=\left(0.05 \alpha q^{5}\right) /\left(\sqrt{g} C^{3} \Delta^{2} D 50\right)
$$

Which is: $\mathrm{q}$ = flow velocity $(\mathrm{m} / \mathrm{s}), \Delta$ = relative density, $\mathrm{C}=$ Chézy friction coefficient and $\alpha=$ Calibration coeficient.

As a result of changes in sediment's volume is the erosion, sedimentation, and arising land. Kenjeran is one of the coastal areas in Surabaya which become trading and service area, as well as tourism area. Therefore, research on coastal morphology changes in Kenjeran, becomes important because of many functions of spatial and population in this region. The results of this analysis can deliver recommendations in the development of Kenjeran area to improve the welfare of the community and reduce environmental problems.

\section{Materials and Method}

This research was conducted in three stages: data collection, hydrodynamics and sediment transport modelling using Delft 3D software and spatial study of Surabaya city. The data used include topographic and bathymetry maps, tidal data, sediment properties data, and Surabaya Spatial Plan $[8,9]$.

Numerical modelling was included the meshing grid, the data input on flow and wave module, and the validation model [3]. This modelling is made to analyze and predict sediment transport movement so that the coastal morphology changes can be seen. The results of this model will be used as a recommendation for the development of Surabaya city in accordance with Surabaya Spatial Plan [8]. In addition, in this study, will also assess the suitability of conditions in the field with the plan by the government in Spatial Planning of Surabaya [8].

\section{Result and Discussion}

The location in this study was at Surabaya. Geographically located at coordinates $7^{\circ}$ $14^{\prime} 00$ " SL (South Latitude) and 112 ${ }^{\circ} 47^{\prime} 02$ "EL (East Longitude). The area reviewed in this study is Kenjeran-Surabaya with the given following data:

1. The average wind direction: $150^{\circ}$

2. Average wind speed: 4 knots

3. Average of incoming wave direction: $110^{\circ}$

4. Significant wave average (Hs): 0.45 meters 
5. Average wave period (T): $5.41 \mathrm{~s}$

6. Total suspended solids (TSS) of sediment: $0.0576 \mathrm{Kg} / \mathrm{m}^{3}$

7. Median sediment grain diameter (D50) : $250 \mu \mathrm{m}$

8. Chezy : 7.5

7. Tidal constants given in Table 1 .

Table 1. Tidal Constants

\begin{tabular}{|c|c|c|}
\hline Tidal Constants & Amplitude (m) & Phase (deg) \\
\hline$M_{8}$ & 0.0049 & 336.15 \\
\hline$S_{4}$ & 0.0046 & 257.33 \\
\hline$M S F$ & 0.0072 & 354.15 \\
\hline$M 4$ & 0.004 & 265.26 \\
\hline$M S_{4}$ & 0.0066 & 55.15 \\
\hline$S_{3}$ & 0.0153 & 08.88 \\
\hline$S_{2}$ & 0.2776 & 332.96 \\
\hline$M_{2}$ & 0.4199 & 334.38 \\
\hline$K_{1}$ & 0.4577 & 288.54 \\
\hline$O_{1}$ & 0.2712 & 267.4 \\
\hline
\end{tabular}

For a more detailed explanation, the following observation points are selected:

Table 1. Observation point location

\begin{tabular}{|l|l|l|}
\hline No & $\begin{array}{l}\text { Observation } \\
\text { points }\end{array}$ & Latitude/Longitude \\
\hline 1. & $(233,326)$ & $\begin{array}{l}\text { Latitude }:-7.205912^{0} \\
\text { Longitude }: 112.774690^{\circ}\end{array}$ \\
\hline 2. & $(280,314)$ & $\begin{array}{l}\text { Latitude }:-7.217450^{0} \\
\text { Longitude }: 112.785840^{\circ}\end{array}$ \\
\hline 3. & $(353,288)$ & $\begin{array}{l}\text { Latitude }:-7.243352^{0} \\
\text { Longitude }: 112.801750^{0}\end{array}$ \\
\hline
\end{tabular}

Based on the result of total transport model was obtained that the data of sedimentation rate in each take at each observation point, where the largest total transport value was occured at the observation point $(233,326)$ as $3.48 \times 10^{-9} \mathrm{~m}^{3} / \mathrm{s} / \mathrm{m}$ and the lowest total transport value at the point of observation $(280,314)$ that is $4.62 \times 10-11$ $\mathrm{m}^{3} / \mathrm{s} / \mathrm{m}$. The results of sedimentation rate values at each observation point can be seen in Table 3 as follows:

Table 2. Sedimentation rate

\begin{tabular}{|c|c|c|c|}
\hline $\begin{array}{c}\text { Observation } \\
\text { point }\end{array}$ & $\begin{array}{c}\text { Bed Load Transport } \\
\text { in Average }\left(\mathrm{m}^{3} / \mathrm{s} / \mathrm{m}\right)\end{array}$ & $\begin{array}{c}\text { Suspended Transport } \\
\text { in Average }\left(\mathrm{m}^{3} / \mathrm{s} / \mathrm{m}\right)\end{array}$ & $\begin{array}{c}\text { Total Transport in } \\
\text { Average }\left(\mathrm{m}^{3} / \mathrm{s} / \mathrm{m}\right)\end{array}$ \\
\hline$(233,326)$ & $5.11 \times 10^{-19}$ & $3.48 \times 10^{-9}$ & $3.48 \times 10^{-9}$ \\
\hline$(280,314)$ & $1.01 \times 10^{-18}$ & $4.62 \times 10^{-11}$ & $4.62 \times 10^{-11}$ \\
\hline$(353,288)$ & $3.38 \times 10^{-18}$ & $3.66 \times 10^{-10}$ & $3.66 \times 10^{-10}$ \\
\hline
\end{tabular}


At the observation point $(233,326)$ in Kelurahan Kedung Cowek, there was sedimentation of $7 \times 10^{-5}$ meters, as evidenced by the change of bed level from -5.6915 meters to -5.9615 meters and also the addition of sediment period from $8025 \mathrm{~kg} / \mathrm{m}^{2}$ to $8025.035 \mathrm{~kg} / \mathrm{m}^{2}$ as shown in Figure 1, Figure 2 and Figure 3.

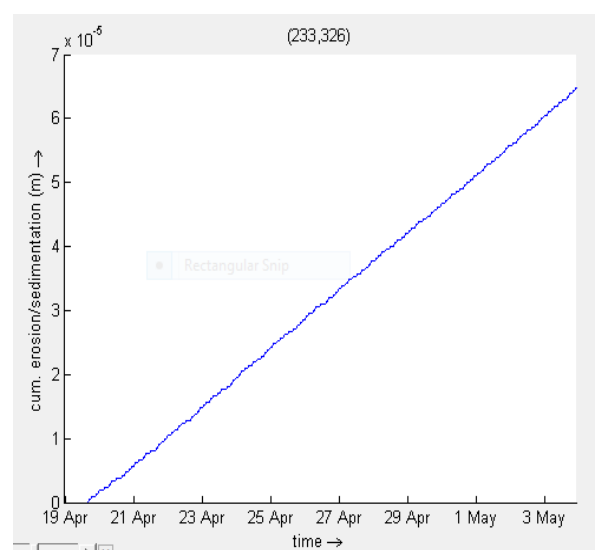

Fig. 1. Cum.Erosion/Sedimentation At Observation Point (233,326)

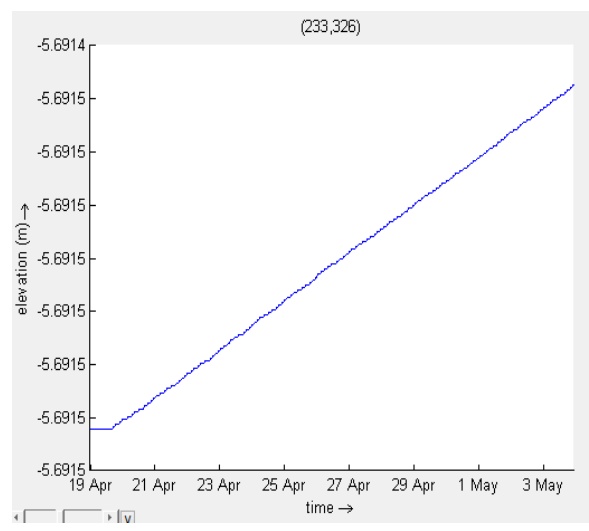

Fig. 2. Bed Level Change At Observation Point $(233,326)$

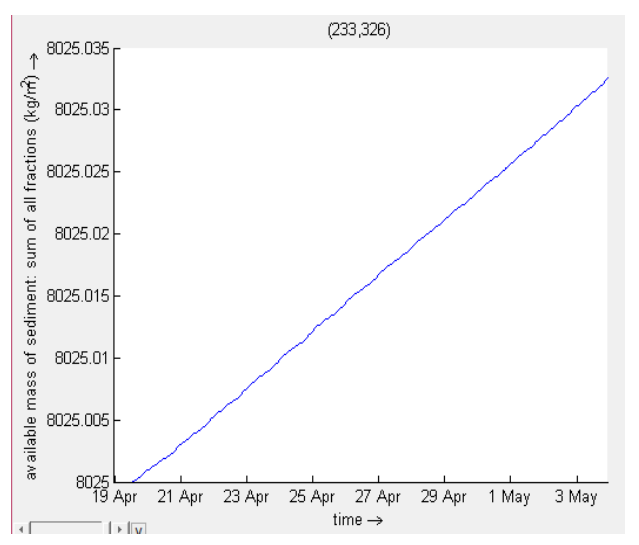

Fig. 3. Available Mass of Sediment At Observation Point $(233,326)$ 
At observation point $(280,314)$ in Kenjeran Sub-district sedimentation occurs $1 \times 10^{-3}$ meter, as evidenced by the change of bed level from -2.4337 meters to -2.4328 meters and also the addition of sediment period from $8025 \mathrm{~kg} / \mathrm{m}^{2}$ to $8025.45 \mathrm{~kg} / \mathrm{m}^{2}$ as shown in Figure 4, Figure 5 and Figure 6.

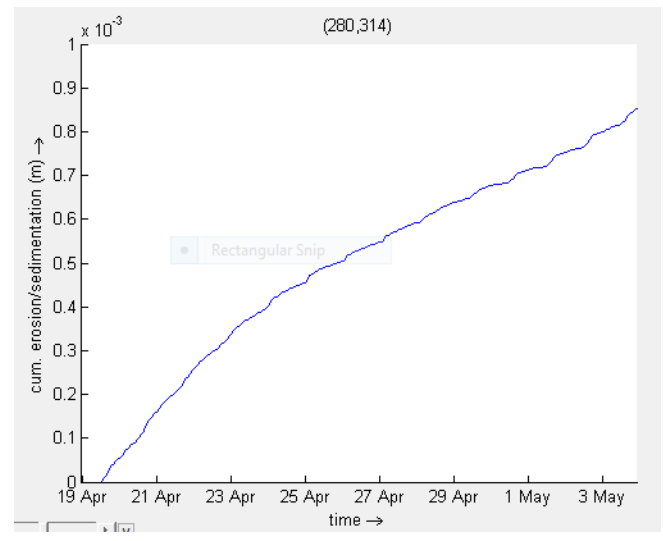

Fig. 4. Cum.Erosion/Sedimentation At Observation Point (280,314)

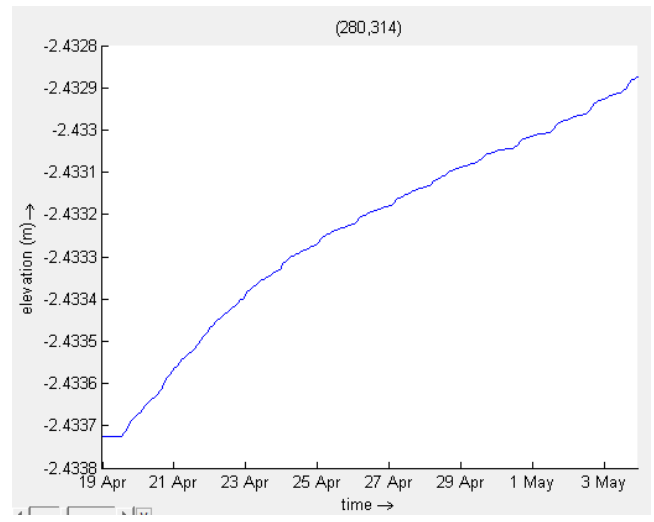

Fig. 5. Bed Level Change At Observation Point (280,314)

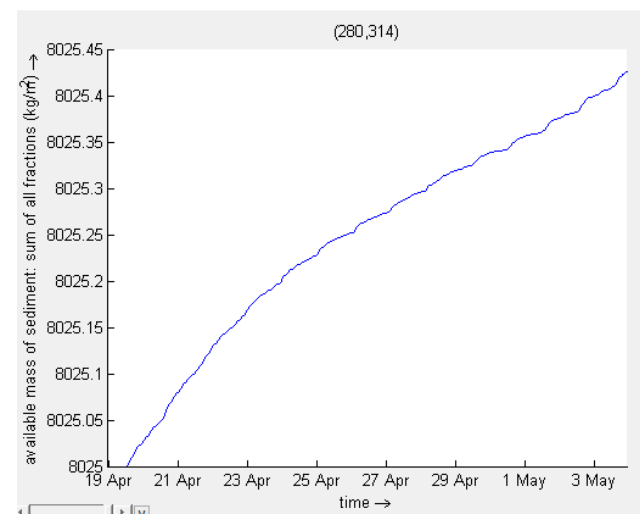

Fig. 6. Available mass of sediment At Observation Point (280,314) 
At observation point $(353,288)$ in Sukolilo Sub-district, sedimentation occurs $4 \times 10^{-3}$ meter, as evidenced by the change of bed level from -1.6345 meters to -1.6305 meters and also the addition of sediment period from $8025 \mathrm{~kg} / \mathrm{m}^{2}$ to $8026.8 \mathrm{~kg} / \mathrm{m}^{2}$ as shown in Figure 7, Figure 8 and Figure 9.

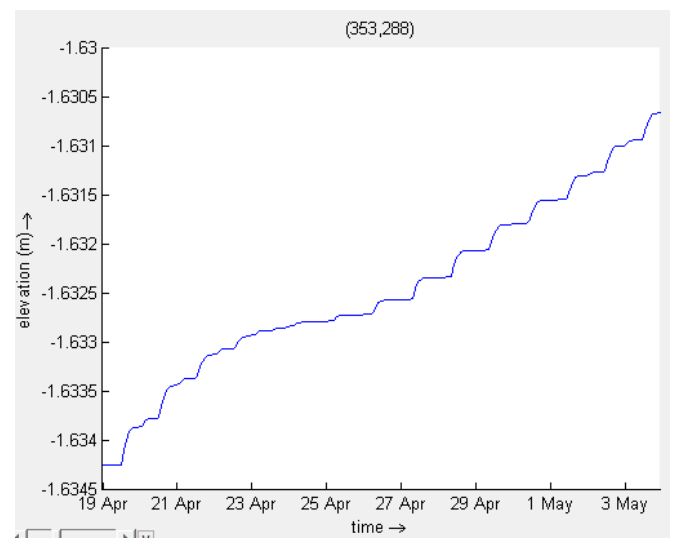

Fig. 7. Cum.Erosion/Sedimentation At Observation Point $(353,288)$

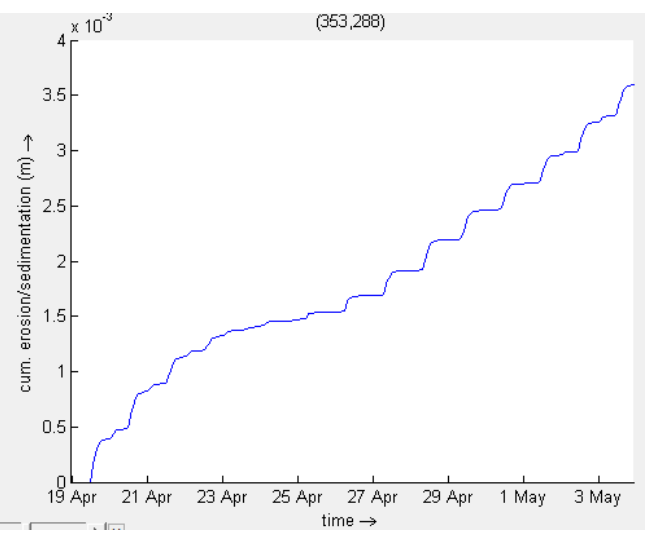

Fig. 8. Bed Level Changes At Observation Point $(353,288)$

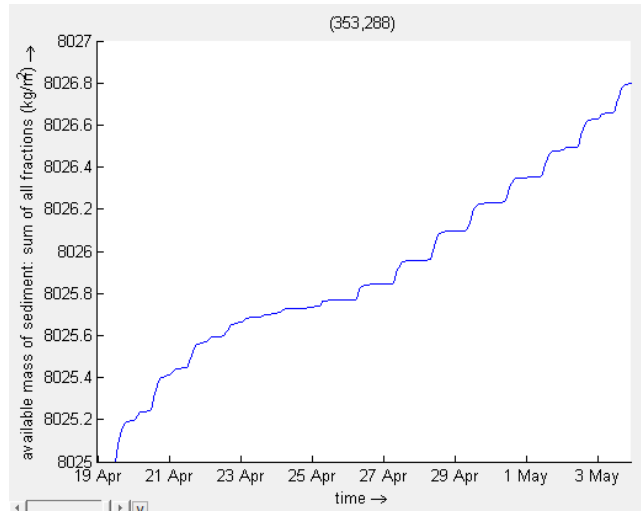

Fig. 9. Available Mass Of Sediment At Observation Point $(353,288)$ 
From Tambak Wedi sub-district to Sukolilo sub-district there is extensive sedimentation, which is $2.3 \times 10^{6} \mathrm{~m}^{2}$ area with sedimentation of $0.02 \mathrm{~m}$ and $7.5 \times 10^{6} \mathrm{~m}^{2}$ with sedimentation of $0.1 \mathrm{~m}$ in the next 15 years based on the sediment transport modelling result as given in Figure 10.

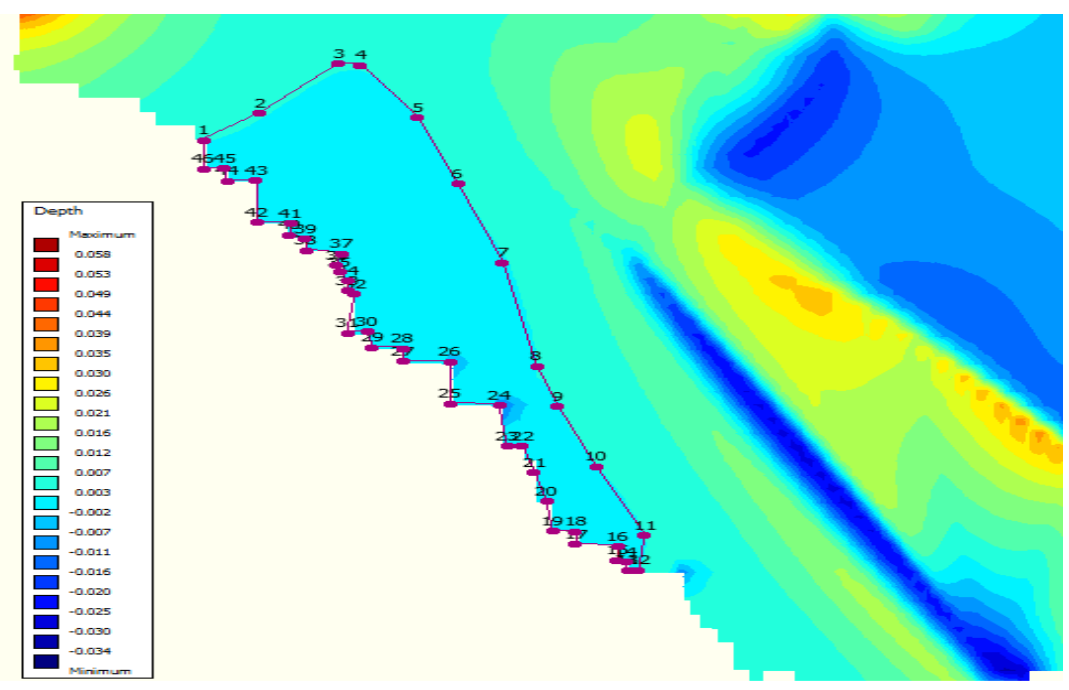

Fig. 10. Sedimentation Accumulation for 15 years

According to the Surabaya City Spatial Plan [8], the area is classified in trade and service areas, and tourism areas. This is in accordance with the conditions in the field that the area is a residential area of fishermen, fishery trading and tourism areas in Old Kenjeran and KenPark. The development of the area by the government is done through:

a. Developing integrated areas of trade and services including provision land for informal traders and built a trading center.

b. Developing an integrated trading area with fulfillment of developer / implementer obligations in the provision of: environmental infrastructure, public utilities, green open space, informal traders and social facilities.

c. Develop and add tourism icons in Old Kenjeran and KenPark.

\section{Conclusion}

Coastal in Tambak Wedi, Kenjeran and Sukolilo Sub-districts are dominated by sedimetation. The use of this area is in accordance with the Surabaya Urban Spatial Plans, but there are some things that must be done in the future development. Such as limiting the use of arising land in the residential areas of fishermen, conducting the development of environment-based tourism and supervise coastal environment from garbage. So that marine ecosystems are not damaged. 


\section{References}

1. CERC. Shore Protection Manual. US Army Coastal Engineering Research Center. Washington. (1984)

2. Z. Liu. Sediment Transport. Laboratoriet for Hydraulik og Havnebygning. Instituttet for Vand, Jord og Miljøteknik Aalborg Universitet (2001)

3. Delft 3D User Manual. Simulation of multi-dimensional hydrodynamic flows and transport phenomena, including sediments. Deltares (2014)

4. Suntoyo, H. Tanaka, and A. Sana. Characteristics of turbulent boundary layers over a rough bed under saw-tooth waves and its application to sediment transport. Coastal Engineering, 55 (12), pp. 1102-1112 (2008).

5. Suntoyo, and Tanaka, H. Effect of bed roughness on turbulent boundary layer and net sediment transport under asymmetric waves. Coastal Engineering, 56 (9), pp. 960-969 (2009).

6. Suntoyo, A.H. Fattah, M.Y. Fahmi, T. Rachman and H. Tanaka. Bottom shear stress and bed load sediment transport due to irregular wave motion. ARPN Journal of Engineering and Applied Sciences, 11 (2), pp. 825-829 (2016).

7. Wijaya, M.M., Suntoyo, and Damerianne, H.A. Bottom shear stress and bed load sediment transport formula for modeling the morphological change in the canal water intake. ARPN Journal of Engineering and Applied Sciences, 11 (4), pp. 27232728 (2016).

8. Review Rencana Tata Ruang Wilayah (RTRW) Kota Surabaya Berdasarkan UU Penataan Ruang No.26/2007 (2009)

9. R. Dahuri. Pengelolaan Sumber Daya Wilayah Pesisir dan Lautan Secara Terpadu. Jakarta. PT. Pradnya Paramita. (1996) 